OPEN ACCESS

Edited by:

Orkun Tolunay

Adana City Training and Research

Hospital, Turkey

Reviewed by:

Gregorio Paolo Milani,

University of Milan, Italy

Fielding Stapleton,

University of Washington,

United States

${ }^{*}$ Correspondence:

Karmila Abu Bakar

karmila@um.edu.my

Specialty section:

This article was submitted to

Pediatric Nephrology,

a section of the journal

Frontiers in Pediatrics

Received: 18 January 2021 Accepted: 16 March 2021 Published: 05 May 2021

Citation:

Abu Bakar K, Jalaludin MY, Zainal N, Woon SL, Mohd Zikre N, Samingan N,

Ab Rahman S and Eng CSY (2021)

Case Report: Severe Hyponatremia in Infants With Urinary Tract Infection.

Front. Pediatr. 9:655010

doi: 10.3389/fped.2021.655010

\section{Case Report: Severe Hyponatremia in Infants With Urinary Tract Infection}

\author{
Karmila Abu Bakar ${ }^{1 *}$, Muhammad Y. Jalaludin ${ }^{1}$, Nur Zainal ${ }^{1}$, Sze L. Woon ${ }^{1}$, \\ Nurwahida Mohd Zikre ${ }^{1}$, Nurshadia Samingan ${ }^{1}$, Syaza Ab Rahman ${ }^{1}$ and \\ Caroline S. Y. Eng ${ }^{2}$ \\ ${ }^{1}$ Paediatric Unit, Faculty of Medicine, University Malaya, Kuala Lumpur, Malaysia, ${ }^{2}$ Paediatric Unit, Hospital Tuanku Ja'afar, \\ Seremban, Malaysia
}

Introduction: Many reports on investigations and treatments in UTI, however little, have been mentioned with regard to electrolyte abnormalities. Secondary pseudohypoaldosteronism (PHA) in UTI, though less common, is a known association. Features include hyponatremia and concomitant hyperkalemia.

Objectives: We aim to highlight these uncommon sequelae in UTI to avoid incorrect diagnosis and unnecessary investigations.

Study Design: Clinical data of patients admitted and referred to a pediatric nephrologist at the University Malaya Medical Center between May 2019 and October 2020 were collated and elaborated.

Results and Discussion: We report three infants with hyponatremia and hyperkalemia during UTI episodes. Two infants were known to have posterior urethral valve (PUV) before the onset of UTI and one infant had UTI, which led to investigations confirming the diagnosis of bladder vaginal fistula. The electrolyte derangements were temporary and resolved within 48 to $72 \mathrm{~h}$ of treatment with intravenous fluid and appropriate antibiotic therapy. Out of three, only one had a hormonal study, which confirms PHA. Reduced aldosterone activity could be due to absolute reduction in aldosterone titer or lack of aldosterone responsiveness at tubular (other tissues) level. In the latter, aldosterone titer is elevated. The infant in our cohort who had hormonal evaluation had the mentioned electrolyte abnormalities with a markedly elevated aldosterone titer. This demonstrated defective action of the hormone at the level of mineralocorticoid receptor. Although the remaining two infants had no confirmatory hormonal study, all of them recovered within $48 \mathrm{~h}$ of hospital admission, after receiving appropriate management for the primary problem, which was UTI. We observed a slower recovery of hyponatremia in relation to hyperkalemia, but none of these infants required salt replacement upon discharge.

Conclusion: Infants with severe UTI and deranged electrolytes should be screened for structural abnormality and vice versa. Not all infants require hormonal screening, but those who required prolonged salt replacement or showed involvement of other systems warrant further evaluation.

Keywords: hyponatremia, hyperkalemia, urinary tract infection, pseudohypoaldosteronism, congenital anomaly of kidney and urinary tract (CAKUT) 


\section{INTRODUCTION}

Urinary tract infection is a common childhood disorder. By 7 years of age, $8 \%$ of girls and $2 \%$ of boys will have at least one episode of UTI (1). In a study of infants presenting to pediatric emergency departments, the prevalence of febrile UTI in infants younger than 60 days was $9 \%$ (2).

Electrolyte abnormalities are commonly observed in children with UTI especially among those who are ill and warrant hospitalization. These abnormalities may be contributed by various reasons, commonly following non-specific symptoms such as vomiting, diarrhea, or reduced oral intake. The utility of hypotonic solutions for maintenance intravenous fluid administration in children exacerbates hyponatremia too; however, this practice has changed in many centers worldwide (3). In severe cases, hyponatremia has been cited to reflect the degree of inflammation. Low sodium has been shown to be independently associated with the degree of inflammation in children with febrile UTI. During severe inflammatory processes, pro-inflammatory cytokines such as interleukin (IL1b) reduces expression of apical epithelial sodium channel and sodium ATPase at the basolateral (4). There is also excess of antidiuretic hormone activity with the rise in IL1b (5). These changes during the inflammatory process lead to a decline in serum sodium. This is usually observed as isolated hyponatremia in the absence of potassium abnormality.

Over the years, guidelines on UTI target optimal antimicrobial management, imaging the urinary tracts, and prevention of recurrence in high-risk groups. Little has been mentioned with regard to electrolyte abnormalities in UTI, which may contribute to patient's morbidity and add to diagnostic challenges. Herein, we report a series of three infants with congenital abnormality of the kidney and urinary tract (CAKUT) presenting with severe hyponatremia and concomitant febrile UTI.

\section{PATIENTS AND METHODS}

Case notes were reviewed critically. All the patients were admitted and referred to a pediatric nephrologist at the University Malaya Medical Center between May 2019 and October 2020. The clinical data of the involved patients were collated and elaborated. We obtained written informed consent from all parents or guardians of the patients involved in the study.

\section{CASE DESCRIPTION}

\section{Case 1}

A 2 month-old boy, with an underlying posterior urethral valve presented with an acute febrile illness. His feedings had been normal. On clinical examination, his growth was at the third centile. His anterior fontanelle was normotensive, and the mucous membrane was moist. The cardiorespiratory and abdominal examinations were unremarkable. His urinalysis showed packed field leukocytes, bacteria, and positive leukocyte esterase. He had severe hyponatremia; serum sodium was 119 $\mathrm{mmol} / \mathrm{L}$ with hyperkalemia, potassium was $6.4 \mathrm{mmol} / \mathrm{L}$, and presence metabolic acidosis. Blood urea and creatinine were
$7 \mathrm{mmol} / \mathrm{L}$ and $43 \mu \mathrm{mol} / \mathrm{L}$, respectively. Extended spectrum beta-lactamase (ESBL) Klebsiella pneumoniae was isolated from his urine. His blood pressure was $112 / 60 \mathrm{mmHg}$. Clinical examination otherwise was unremarkable. He did not show signs of virilization. During the episode of illness, hormonal evaluation showed hyperaldosteronism with normal 17-hydroxyprogesterone [aldosterone of 15,428 pmol/L (102$1,197 \mathrm{pmol} / \mathrm{L})$ and $17-\mathrm{OHP}$ of $3.8 \mathrm{nmol} / \mathrm{L}(0.97-10 \mathrm{nmol} / \mathrm{L})]$. The electrolyte abnormalities improved with standard therapy for UTI (administration of intravenous fluid and antibiotic) within $48 \mathrm{~h}$ of hospital admission. At 3 months post-infection, his dimercaptosuccinic acid (DMSA) scan showed scarring at the right upper pole with right to left differential function of 31 and $69 \%$.

\section{Case 2}

A 2-month-old girl presented with the first episode of UTI. She had high-grade fever for 3 days associated with foul-smelling urine. She had no vomiting, and her oral intake was normal. She was born full term with birth weight of $3.2 \mathrm{~kg}$. Both antenatal and immediate postnatal periods were uneventful. Her growth had been along the 50th centile. On arrival at the hospital, her BP was $116 / 66 \mathrm{mmHg}$. Her anterior fontanelle was normotensive, and she had moist mucous membrane. Apart from a soft systolic murmur, no other abnormalities were detected. Her electrolytes were severely deranged: serum sodium of $116 \mathrm{mmol} / \mathrm{L}$, potassium of $7 \mathrm{mmol} / \mathrm{L}$, and presence of metabolic acidosis. Urine culture grew Pseudomonas aeruginosa. Intravenous fluid and antibiotics were instituted. Hyperkalemia and acidosis were resolved within $48 \mathrm{~h}$ of therapy, but she needed oral sodium replacement for a further $24 \mathrm{~h}$. Evaluation post-UTI showed right hydronephrosis with an anteroposterior renal pelvic diameter of $1.7 \mathrm{~cm}$ and an abnormal connection between the bladder and vagina on micturition cystourethrography (MCUG). She was then referred to the surgical team for corrective surgery. While waiting for the surgery, she suffered another two episodes of UTI despite started on antibiotic prophylaxis. In both episodes, the electrolytes were deranged in the same fashion. After the correction of the vesicovaginal fistula, no recurrence of UTI was observed, and her electrolytes remained normal. She was planned for a DMSA to assess the degree of her kidney scarring.

\section{Case 3}

An 8-month-old boy was born full term at 38 weeks with birth weight of $3.26 \mathrm{~kg}$. Antenatally, he was diagnosed to have bilateral gross hydronephrosis at 30 weeks of gestation. Postnatal kidney ultrasound showed bilateral gross hydronephrosis with thinning of the cortex. His MCUG suggested a posterior urethral valve, and he had valve fulguration at 6 weeks old. He was thriving steadily within the range of 15 th to 50th centile. Otherwise, physical examination was unremarkable. Unfortunately, he continued to suffer from recurrent episodes of UTIs. Typically, he would only present with fever. There was no vomiting or changes in his oral intake. His urine cultures consistently yielded ESBL Enterobacter cloacae. In three out of the five episodes, serum electrolytes showed hyponatremia (the lowest was $112 \mathrm{mmol} / \mathrm{L}$ ) and hyperkalemia (highest serum potassium level at $6.4 \mathrm{mmol} / \mathrm{L}$ ). 
TABLE 1 | Clinical characteristics and laboratory data of infants with severe hyponatremia.

\begin{tabular}{|c|c|c|c|}
\hline & Case 1 & Case 2 & Case 3 \\
\hline Age (months) & 3 & 2 & 8 \\
\hline Gender & Male & Female & Male \\
\hline $\begin{array}{l}\text { Serum } \mathrm{Na} \\
(\mathrm{mmol} / \mathrm{L})\end{array}$ & 119.0 & 116.0 & 112.0 \\
\hline Serum K (mmol/L) & 6.4 & 7.0 & 6.4 \\
\hline $\begin{array}{l}\text { Serum creatinine } \\
(\mu \mathrm{mol} / \mathrm{L})\end{array}$ & 43.0 & 40.0 & 40.0 \\
\hline Serum pH & 7.18 & 7.31 & 7.30 \\
\hline $\begin{array}{l}\text { Serum } \\
\text { bicarbonate } \\
(\mathrm{mmol} / \mathrm{L})\end{array}$ & 14 & 16 & 17 \\
\hline $\begin{array}{l}\text { Serum chloride } \\
\text { (mmol/L) }\end{array}$ & 91 & 89 & 85 \\
\hline Serum anion gap & 20 & 19 & 20 \\
\hline $\begin{array}{l}\text { Serum aldosterone } \\
(\mathrm{pmol} / \mathrm{L})\end{array}$ & $15,428.0$ & - & - \\
\hline $\begin{array}{l}\text { Serum } \\
17-\mathrm{OHP}(\mathrm{nmol} / \mathrm{L})\end{array}$ & 3.8 & - & - \\
\hline $\begin{array}{l}\text { Identified structural } \\
\text { abnormality }\end{array}$ & $\begin{array}{l}\text { Posterior urethral } \\
\text { valve }\end{array}$ & Vesico-vaginal fistula & $\begin{array}{l}\text { Posterior urethral } \\
\text { valve }\end{array}$ \\
\hline $\begin{array}{l}\text { Organism cultured } \\
\text { from urine }\end{array}$ & $\begin{array}{l}\text { ESBL Klebsiella } \\
\text { pneumonia }\end{array}$ & $\begin{array}{l}\text { Pseudomonas } \\
\text { aeruginosa }\end{array}$ & $\begin{array}{l}\text { ESBL } \\
\text { Enterobacter } \\
\text { cloacae }\end{array}$ \\
\hline $\begin{array}{l}\text { Method of urine } \\
\text { collection }\end{array}$ & $\begin{array}{l}\text { In-out } \\
\text { catheterization }\end{array}$ & $\begin{array}{l}\text { In-out } \\
\text { catheterization }\end{array}$ & $\begin{array}{l}\text { In-out } \\
\text { catheterization }\end{array}$ \\
\hline $\begin{array}{l}\text { Organism count } \\
(\mathrm{CFU} / \mathrm{ml})\end{array}$ & $>10^{5}$ & $>10^{5}$ & $>10^{5}$ \\
\hline
\end{tabular}

These electrolyte abnormalities improved markedly each time with prompt antibiotic therapy and short-term oral sodium replacement. At the time of writing, DMSA was still pending.

\section{DISCUSSION}

Acute hyponatremia is potentially detrimental to health. In an already ill child with febrile UTI, this could compound to disease-related morbidity. In our series, all infants had severe hyponatremia and hyperkalemia at the time of presentation (Table 1). Such "blueprints" reflected a state of reduced aldosterone activity. It was important to ensure that masquerading underneath these biochemical abnormalities was not a potentially life-threatening differential diagnosis of congenital adrenal hyperplasia (CAH). A milder form of $\mathrm{CAH}$ that presents much later may not show virilizing signs initially, while those who developed electrolyte abnormalities early should demonstrate some evidence of virilization (6). It is worth noting that all three of our patients presented early within their first year of life, and none showed virilization. This made the possibility of $\mathrm{CAH}$ less likely. A normal level of 17 hydroxyprogesterone excludes the possibility of CAH as well.

Various factors contribute to the development of hyponatremia in UTI. Poor fluid and caloric intake, frequent regurgitations, loose stools, and renal unresponsiveness to aldosterone are among the likely cause (7). In depletional hyponatremia, concurrent hyperkalemia is not observed, or rather, potassium may be low due to the rapid rise of potassium excretion in response to the loss of sodium (8). A complete history taking and thorough physical examination should not be underestimated; although simple, it is important in differentiating possible causes of hyponatremia (9) and to guide on the subsequent management.

Serum sodium in our cohort was measured using indirect potentiometry. Compared with direct potentiometry, the samples are diluted first before in contact with ion-selective electrodes (ISE). Electrolyte concentration in the diluted sample is calculated assuming that plasma water concentration is $93 \%$. We acknowledge that variation in serum sodium exists when determined via different laboratory techniques. Milani et al. compared serum sodium analyzed by direct and indirect potentiometry and found that the former is superior. The determinants of incongruity were age, hemoglobin, age and albumin, and albumin and hemoglobin (10). This potential incongruence due to laboratory techniques is minimized by utilizing the same method for serial monitoring.

Low serum sodium and high serum potassium were hallmarks of reduced aldosterone activity. This could be due to absolute reduction in aldosterone titer or lack of aldosterone responsiveness at tubular (other tissues) level (11). In the latter, aldosterone titer is elevated. One infant in our cohort had hormonal evaluation, which supported pseudohypoaldosteronism. He had the mentioned electrolyte abnormalities and a markedly elevated aldosterone titer. This demonstrated a defective action of the hormone at the level of mineralocorticoid receptor (12). Although, the remaining two infants had no confirmatory hormonal study, all of them recovered within $48 \mathrm{~h}$ of hospital admission, after receiving appropriate management for the primary problem, which was UTI. We observed slower recovery of hyponatremia in relation to hyperkalemia, but none of these infants required salt replacement upon discharge.

The actions of aldosterone have been well described. At the cortical collecting duct, aldosterone increases the activity of basolateral $\mathrm{Na} / \mathrm{K}$ ATPase, luminal expression of epithelial sodium channel $(\mathrm{ENaC})$, and the activity of luminal renal outer medullary potassium (ROMK) channels (13). This favors absorption of sodium and excretion of potassium under normal circumstances. Mutations of genes regulating these channels occur in primary pseudohypoaldosteronism (PHA), both type I and type II. Mutations in the epithelial sodium channel (EnaC) lead to autosomal recessive form of PHA type 1, whereas the autosomal dominant form is characterized by mutations in the mineralocorticoid receptor. In PHA type 1, the key clinical features would be hyponatremia, hypovolemia, hyperkalemia, and metabolic acidosis. PHA type II or Gordon syndrome is a resultant of mutations in a family of serine-threonine kinases [with-no-lysine kinases (WNK)1 and WNK4]. WNK4 inhibits expression of sodium chloride $(\mathrm{NaCl})$ cotransporter (NCC). Hence, in PHA type II, mutation of WNK4 increases sodium reabsorption while minimizing potassium loss leading to the syndrome of hypertension and hyperkalemia (13). Secondary 
pseudohypoaldosteronism has been reported in young infants presenting with UTI with or without urinary tract anomalies, with biochemical abnormalities mimicking that of PHA type 1 (14-17).

Delforge et al. examined a series of 116 infants with secondary pseudohypoaldosteronism and CAKUT. Only $10 \%$ showed such biochemical abnormalities in the absence of UTI (11). All the patients in our cohort had underlying CAKUT. Interestingly, the secondary pseudohypoaldosteronism recurred during every episode of UTI, and in the second case, this ceased after urological correction. Our observation concurred with the case series reported in the past. This suggests the importance of screening electrolytes for infants with CAKUT. Vice versa, in young infants with known CAKUT presenting with UTI, electrolyte evaluation is necessary, and it is worth to consider secondary pseudohypoaldosteronism. As the latter is transient, early recognition would allow appropriate management, while we expectantly monitor for recovery with time. In a resourcelimited environment like in our centers, this may safely avoid unnecessary endocrinology workup at the first instance. Furthermore, long turn-around time with hormonal testing makes it less feasible to guide on immediate management.

\section{REFERENCES}

1. Williams G, Craig JC. Long-term antibiotics for preventing recurrent urinary tract infection in children. Cochrane Database Syst Rev. (2019) CD001534. doi: 10.1002/14651858.CD001534.pub4

2. Zorc JJ, Levine DA, Platt SL, Dayan PS, Macias CG, Krief W, et al. Clinical and demographic factors associated with urinary tract infection in young febrile infants. Pediatrics. (2005) 116:644-8. doi: 10.1542/peds.2004-1825

3. Wang J, Xu E, Xiao Y. Isotonic versus hypotonic maintenance IV fluids in hospitalized children: a meta-analysis. Pediatrics. (2014) 133:10513. doi: 10.1542/peds.2013-2041

4. Park SJ, Oh YS, Choi MJ, Shin JI, Kim KH. Hyponatremia may reflect severe inflammation in children with febrile urinary tract infection. Pediatr Nephrol. (2012) 27:2261-7. doi: 10.1007/s00467-012-2267-9

5. Eisenhut M. Changes in ion transport in inflammatory disease. J Inflamm. (2006) 3:5. doi: 10.1186/1476-9255-3-5

6. White PC, Speiser PW. Congenital adrenal hyperplasia due to 21 hydroxylase deficiency. Endocrine Rev. (2000) 21:245-91. doi: 10.1210/edrv.21.3.0398

7. Milani GP, Grava A, Bianchetti MG, Lava SAG, Dell "Era L, Teatini T, et al. Electrolyte and acid-base abnormalities in infants with communityacquired acute pyelonephritis: prospective cross-sectional study. Nephron. (2017) 137:99-104. doi: 10.1159/000478054

8. Kassirer JP, Schwartz WB. The response of normal man to selective depletion of hydrochloride acid: factors in the genesis of persistent gastric alkalosis. Am J Med. (1966) 40:10-8. doi: 10.1016/0002-9343(66)90182-3

9. Bertini A, Milani GP, Simonetti GD, Fossali EF, Faré PB, Bianchetti MG, et al. $\mathrm{Na}(+), \mathrm{K}(+), \mathrm{Cl}(-)$, acid-base or $\mathrm{H} 2 \mathrm{O}$ homeostasis in children with urinary tract infections: a narrative review. Pediatr Nephrol. (2016) 31:14039. doi: 10.1007/s00467-015-3273-5

10. Milani GP, Edefonti V, De Santis R, Agostoni C, Spolidoro GCI, Pelucchi $\mathrm{C}$, et al. Disagreement between direct and indirect potentiometric $\mathrm{Na}+$ determination in infancy and childhood. Clin Chem Lab Med. (2020) 58:e1179. doi: 10.1515/cclm-2019-0931

11. Gross P, Heduschka P. Inherited disorders of sodium and water handling. In: Floege J, Johnson RJ, Feehally J, editors. Comprehensive Clinical Nephrology. 4th ed. Mosby St. Louis, MO (2010). p. 573-83.
Nevertheless, we reckon that infants who showed delayed resolution may benefit from the further hormonal investigation.

In conclusion, the presence of CAKUT in all the cases illustrated in this series supports monitoring of electrolytes in a child with UTI when CAKUT is present.

\section{DATA AVAILABILITY STATEMENT}

The original contributions presented in the study are included in the article/supplementary material, further inquiries can be directed to the corresponding authors.

\section{ETHICS STATEMENT}

Written informed consent was obtained from the individual(s), and minor(s)' legal guardian/next of kin, for the publication of any potentially identifiable images or data included in this article.

\section{AUTHOR CONTRIBUTIONS}

All authors listed have made a substantial, direct and intellectual contribution to the work, and approved it for publication.

12. Arai K, Papadopoulou-Marketou N, Chrousos GP. Aldosterone deficiency and resistance. In: Feingold KR, Anawalt B, Boyce A, Chrousos G, Dungan K, Grossman A, et al., editors. Endotext. South Dartmouth, MA: MDText.com, Inc. (2000).

13. Furgeson SB, Linas S. Mechanisms of type I and Type II pseudohypoaldosteronism. J Am Soc Nephrol. (2010) 2:18425. doi: 10.1681/ASN.2010050457

14. Delforge X, Kongolo G, Cauliez A, Braun K, Haraux E, Buisson P. Transient pseudohypoaldosteronism: a potentially severe condition affecting infants with urinary tract malformation. J Pediatr Urol. (2019) 15:265.e1-7. doi: 10.1016/j.jpurol.2019.03.002

15. Schoen EJ, Bhatia S, Ray GT, Clapp W, To TT. Transient pseudohypoaldosteronism with hyponatremiahyperkalemia in infant urinary tract infection. $J$ Urol. (2002) 167:680-2. doi: 10.1097/00005392-20020200000063

16. Rodriguez-soriano J, Vallo A, Oliveros R, Castillo G, Bilbao MD. Transient pseudohypoaldosteronism secondary to obstructive uropathy in infancy. J Pediatr. (1983) 103:375-80. doi: 10.1016/S0022-3476(83)8 0406-5

17. Memoli E, Lava SAG, Bianchetti MGP, Vianello F, Agostoni C, Milani GP. Prevalence, diagnosis, and management of secondary pseudohypoaldosteronism. Pediatr Nephrol. (2020) 35:713-4. doi: 10.1007/s00467-019-04419-z

Conflict of Interest: The authors declare that the research was conducted in the absence of any commercial or financial relationships that could be construed as a potential conflict of interest.

Copyright (c) 2021 Abu Bakar, Jalaludin, Zainal, Woon, Mohd Zikre, Samingan, $A b$ Rahman and Eng. This is an open-access article distributed under the terms of the Creative Commons Attribution License (CC BY). The use, distribution or reproduction in other forums is permitted, provided the original author(s) and the copyright owner(s) are credited and that the original publication in this journal is cited, in accordance with accepted academic practice. No use, distribution or reproduction is permitted which does not comply with these terms. 